\title{
INFLUENCE OF THE GREEK LANGUAGE ON THE SPEECH AND FOLK POETRY OF GORA
}

Sadik Idrizi ${ }^{1}$

Facutly of Education, University of Prizren

Received: 22.01 .2012

Accepted: 02.03.2012
Review paper

\begin{abstract}
Based on its many structural features, the Gorani dialect belongs to Balkan linguistic union. Some features have joined this dialect as a result of lingustic and ethnic mixtures present in the southeastern part of Balkan peninsula. Romanic, Turkish and Greek languages have influenced a lot the creation of the Balkan linguistic association. Balkan languages show a lot of parallel features in phonetics, morphology, suntax and vocabulary.
\end{abstract}

Key words: Gora, Gorani dialect, Balkan language union, Greek language, impact.

\section{INTRODUCTION}

Population movement was present in Balkans since ancient times, which created conditions for language contacts and interference. Based on many structural characteristics, Gorani speech belongs to Balkan linguistic union. Some characteristics have become part of this speech as a result of lingustic and ethnic mixture in southeastern part of Balkan Peninsula. (Mladenović, 2001, p. 536) Roman languages, as well as Turkish and Greek as well, had influence on establishment of Balkan linguistic union. Linguistic union means bilingualism or multilingualism, whereas in mixogloty, a simplified system by which a sort of distinction within linguistic strucutre is being removed. (Ivić, 1991, p. 16)
Balkan languages show many parallel features in phonetics, morphology, syntax and lexicon. Because of the constant population movemnet, Gorani speech was exposed to the influence of almost all Balkan languages. Many Gorani people, because of the cattle breeding and trade, have used few languages at the same time. Beside their own language, many man was able to speak Turkish, Albanian, Aromanian and Greek languages, which have resulted in having many borrowed words in Gorani languages, coming from mentioned languages.

Numerous calc in Balkan languages witness aboute very intensive relation between them and confirms accurancy of the stance, which by explaining

1 Correspodence to:

Sadik Idrizi, PhD, Faculty of Education, University of Prizren Bingen str. DII/5, Prizren, Kosovo

Phone: + 37744200915

E-mail: aljabak54@yahoo.com 
phonological and grammatical phenomena in them, gives important place to the inter-lingual contact in Balkan environment. It is not rare case that the words and, especially, phraseological expressions of given internal form, can be found in all languages (or at least many languages) of Balkan environment. (Koneski, 1966, pp. 182-183) In Gorani language, a series of calcs is evident, and the same are undertaken from these, by their origin, very various languages. Sometimes, it seems that, by „depth structure“ (Chomsky, 1972), Gorani language is getting closer to non-Slavic langusges, with wich it have shared the joint space for centuries. In these kind of cases, it is not easy to determine which language have used as source of borrowing, although it is daubtless that Greek, later Turkish language as well, have left the bigest part of the traces when it comes to modelling the Balkan lexicon.

\section{DISCUSSION}

1.

Area of Gora is $200 \mathrm{~km}$ away from Greece. However, through the history it can be seen that the Greek presence and Greek influence in Gora were stronger. Until late, even after the ruination of Ottoman empire, many cattleman from Gora had taken their sheeps for grazing to Salonika, Janina and other places in Greece, especially during the winter season. It is also worth mentioning that many Gorani people had their craft stores in many Greek towns: Salonika, Kavala, Janina, ect. Especially Gorani people coming from Brod village had very strong contacts with Greece. As a result of those realtions, a coin násolun was created in Brod village, which was marking the meaning of working abroad. This term does not determines the fact working abroad only for Saloniki, but it have received its meaning and become a synonym for working abroad. (Bábajko mi óšoǔ násolun - „My father went to work abroad").

Salonika and other towns in Greece are very often mentioned in folk poetry of Gora. Salonika (Seljanik) have been mentioned in songs very often, but Kavala, Janina and other as well.

„Solunsko pole, male, suša kažuje“ (Dokle, 2000, p. 157); „Solunsko polje suša kažujet" (Hasani, 1987, p. 53); „,solunsko somunče“ (Hasani, 1987, p. 90); ,će zimate devojka Solunka“ (Hasani, 1987, p. 144); „dva bela đuguma, obadva solunsće (Hasani, 1987, p. 337); Go fatile, nuse mori, vo Seljanik. (Dokle, 2000, p. 192) „,vo Kavala, Nurke ćerko, vo apsana“ (Hasani, 1987, p. 1);

„Daj mi bože krila labodove Ja da letam, dur devet planine, Pa da panem vo Solunsko pole, Da odberem Bošnjaka junaka.“

(Dokle, 2000, p. 168)

In village Orčuša there is a family Seljanikovci, which got this name because of the male family members that were staying on Salonika (Seljanik) during the winter months along with the sheeps.

Contacts with Greek language are much older and were existing far earlier. Some toponyms and names of the medieval documents also shows this. In the charter of Holy Archangels from 1348, certain Draica Grkovik from Jelenca village is being mentioned.based on the borders given there, Jelence could be the name of today's Baćka village, or neighbourhood which was located in vicinity. Some toponyms that have been saved up to date in Gora, can be linked with the Greek language: Grkinica, Gŕkojec, Grčké rupe, Grčkó 
trlo, Gramatnikojec, Páraspur Perívolji, Strátorje, Mávra etc. These influences could have go through Aromanians as well, which were, as nomads, alogn with the cattles, searching for better pastures and thus moving from Pinda and Gramos till Bistra, Korab and Sar mountain.

\section{2.}

In Gorani speech and national poetry of Gora, a considerable number of verbs under the influence of Greek language with suffixes have been established $-(i / o) s a$. Suffix $-s a$ is present only in verbs of Greek origin, while siffixes -isa and -osa have went into verbs with Turkish basis through the verbs with Greek basis.

However, by using suffix -osa some domestic verbs of unknown origin are also being established: kŕvjosa, cŕvjosa, jádosa, zídosa, gnjídosa, hŕđosa, trupjosa, kislosa, žgljibosa, špirtosa, pcojsa (die), utisa (win in a game), kruposa (overeat), etc.

Number of verbs coming from Greek language that have entered Gorani speech is not negligible. Here we bring some verbs for which have been determined that they are of Greek origin, even though we still have a number of verbs and words in this language which usualy leads to Greek language, but whose origin has remained as unknown and insufficiently researched.

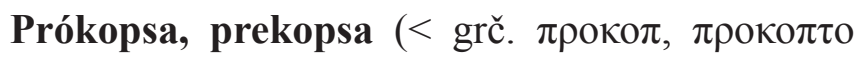
$\pi \rho о к о \psi \alpha)-$ progress, make it in life, get lucky, as well as derivates coming from this verb prokopsanik and prokopsánica, limited in Zljipotok, Kruševo, Resteljica, Brod, Šištejec and some more villages: Voživot nema da prokopsa. Ne prokopsalje so toljko stoka. Nikoj ne prokopsaf so tuđo. Prokopsanik jeden ima da viđi.
Stása $(<$ grč. $\phi \tau \alpha \nu \omega)$ - arrive, come, mature, Gora: Ako ne staset kamenete, će ostanet. Ne mi stasuje seno duri sret zima. Ne zn'm a će im stase lebot (Dokle, 2007).

Stasaf za ženjene. Stasaf na vreme vo školo.

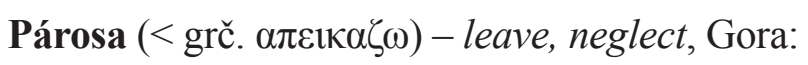

Parosala deca i se omužila. Som parosaf sebe za nih i jope loš. Ne se parosuje mati ka ti šo si ga parosaf. I mije zborime za parosujene (Dokle, 2007).

„rezilj će te napraj, Fato be ćerko, / pa će te parosa“ (Hasani, 1987, p. 188),

„Parosaj go, kuzum Nurke, Ašim ćaja.“ (Hasani, 1987, p. 1)

„Ka će ge parosam, mila nan' mori, gorske planine.“ (Hasani, 1987, p. 261)

Píkosa, zapíkosa $(\alpha \pi \varepsilon 1 \kappa \alpha \zeta \omega)$ - notice, remember, differentiate, Gora:

Odjenoš go zapikosa da ima nešto. Ako ne sve, nekuje stvari trebe da se zapikosaje. Oni bilje otdamno zapikosane (Dokle, Rječnik).

Prépsa (< grč. $\pi \rho \varepsilon \pi \omega)$ - look like, resemble someone, Gora:

Ne prepsa na brata. Mi prepsa na nekogo, ama ne možem da se setim na kogo.

Máđosa (< grč. $\mu \alpha \gamma \varepsilon v \omega)$ - fascinate, mesmerize, Gora:

Go mađosalje i veće ne viđi druga osim nah. Ako je mađosana šo nejće nikogo (Dokle, Rječnik).

„So kogo bilo, mori nane, koj go mađosa, nanice, koj go arosa. (Hasani, 1987, p. 412),

„Go arosale, ja mlajnesto, go mađosale!“ (Hasani, 1987, p. 412)

Vápsa/vápca $(<$ gr. $\beta \alpha \varphi \omega)$ - color, figuratively charge, Gora:

Ne si ga vapcaf hubavo fanuljata. Gajtanot ne ti je vapcan hubavo. Si go vapcaf pantulot ni da si se valjaf negde. Vapcujeneto mi se sm'tni (Dokle, 2007). 
Árosa. The verb was created out of very frequent noun aro („misfortune“) which is also beloning to Greek language. In the language, it is used as exclamation- ,,misfortune“", ,ruth“:

Idte, aro, šo mi sedite zakuane ovde! „,Trnite mi se ot glava, aro! (Dokle, Rječnik),

ali i kao imenica: „Ajrijo, aro te udrilo“, (Hasani, 1987, p. 139).

As a verb, it can be seen with the meaning ,come to grief". Following derivatives has come from it arósanik, arosánica (wretch, poor woman):

„Go arosale, ja mlajnesto, go mađosale!“‘ (Hasani, 1987, p. 412)

Díplosa, zdiplosa, dipli (< grč. $\delta 1 \pi \lambda \omega \sigma \varepsilon 1)-$ fold, arrange, align, Gora:

Sve beše zdiplosano i uredeno vo kućata. Haljištata zdiposane i stajene na mesto, take i postelje i sve vo dolap. Zdiplosuje postelja (Dokle, 2007).

Vítosa (,break the neck"), Gora:

Će mu se vitosam vo pare nejdzine. Pa ne i se vitosaj vo hizmet nejdzin. Će mu se vitosam i tija hubavo (Dokle, 2007).

Pŕsa (be in hurry, putter) Gora:

Nazif prsa mlogo. Ne ga prsaj rabotata dur ne isprašaš hubavo. Ovja je prsana rabota. Za prsanevo mlogo puti sme se karalje (Dokle, 2007). Árniša (< grč. $\alpha \rho v o v \mu \alpha l, \alpha \rho v \eta \sigma o \mu \alpha \mathrm{l})$ - postpone, leave, refuse, Gora:

Evo tri puti ka se arnišujem, deneska će trnem. Sam se arnišaf, sega velji zašto mi ste arnišalje. Zaradi nego se arnišane (Dokle, 2007).

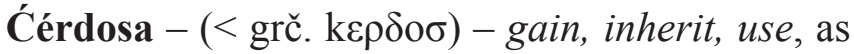
well as derivatives ćerdosanik and ćerdosanica with pejorative meaning, Gora:

Imanevo go ćerdosaf od starbabeta. Da se ćerdosate. (Dokle, 2007).

„da ge nosi da ne ge ćerdosa“ (Hasani, 1987, p. 185)

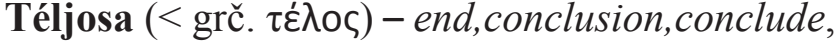
limited to Brod only:

Rabotata ḱe ga teljosame. Agmetu oja mu je teljos.

Based on shape and suffix $-s a$, event though it's origin is unknown to us, a number of verbs in Gorani speech, could have connections to the Greek language:

Déksa (suffer, endure, accept), unknown origin, Gora:

Mlogo go deksaš deteto. Ja on je deksan, ja nikoj. (Dokle, 2007).

Utisa (benefit, gain, gain from the opponent), unknown origin, Gora:

Sve pare mu ge utisalje na Sretsela. „mi ga jutisale baš prva sadica“" (Hasani, 1987, p. 120)

Votrosa (be assertive, impose), unknown origin, Gora:

Ka mi se votrosa, što da ti rečem. Ne mu se votrosuj drugatomu, beljki nema da ti dade. $\mathrm{Ne}$ zn'š šo votrosan je on. Po votrosan go nema (Dokle, 2007).

3.

Many nominal words, some of them directly and som eof Turkish origin, have become part of Gorani language and national poetry of Gora from Greek language:

$\operatorname{Los}(\mathbf{t})(<$ grč. $\lambda \circ \sigma \tau)-$ lever, Gora:

Trupje sme ge tuarilje na traktor so lostoj. Mu se skrši lost i za malo da mu se fati noga.

Angarija, angerija (< grč. $\alpha \gamma \gamma \alpha \rho \varepsilon 1 \alpha)-$ work, work without compensation, without control, Gora:

„Na vreme austriačko ne teralje da rabotame angeria.“ „Beše ste ga izrabotalje angerija“ (Dokle, 2007); Konji ge puštilje angarija. Sve je više angarija. 
Sinor (grč. oúvopov) - the boundary, limited to Borje and few more villages. In Balkan it is a of Greek origin.

Pálav (stupid,insane, wild): Kojni gi popalajef. Pušti go, on je palaf.

„čukni ga glava palava“, (Hasani, 1987, p. 59) „More bećare, glavo palava.“ (Dokle, 2000, p. 262).

Pálanca (big beam scale):

Meso sme go merilje so palanca. (Kruševo);

Prófir/ka ( picky person, approach the food, sweet, treat):

Ti si profir. Toja profir ne stava ljep vo usta. Ljep je direk, ovja se profirske. (Dokle, 2007); Ljep ne jade, samo profirke saka.

Félija (piece, steak):

Som zef dve felije maznik. Jena felija ot

baklavata, kakve me udri, toljko što beše mrsna (Dokle, 2007).

Kókalo (bone, big bone):

„Sinojka, dado, sme se karale, za jeno pusto kokalo, džanam,“"(Hasani, 1987, p. 287)

Štírka (sterile sheep, sterile person):

„Kerim ćehaja, mori, samo jena štirka.“ (Dokle, 2000, p. 158);

Nouns pízma (hatred), šájka (nail), dŕman (rare sieve), pljít (adobe), dímije, eféndija, furna, fenjer are of Greek origin. They've joined Gorani language directly or through Turkish language.

\section{4.}

Very charachteristic exclamation present within Gorani speech and national poetry of Gora more/ ore, mori/ori, as well as contracted forms bre/be are adopted from Greek language. (grč. $\mu \omega \rho \varepsilon$, $\mu о \rho \eta$, which represents, originally, vocative of $\mu$ opos „,crazy“). Form móre is used for male gender, while form móri is used with the nouns of female gender.

Exclamation diko is used parallely. All these forms are especially present in national verbal poetry:

„Mori majko, momci me vikaje,

More momci, pogača da mesim“ (Dokle, 2000, p. 55);

Greek phrase for showing the good will $\sigma \pi \circ \lambda \lambda \alpha$ $\varepsilon \tau \eta$ are translated as ,for many more years to come“. Same phrase, but only directly taken in form of bola ${ }^{\mathbf{j}} \mathbf{e c} i$, have different meaning in Gorani language: „God forbid“, „I wish“. This form have the meaning of spolajti in Macedonian language.

Bolájeći da ne se vratš. Bolájeći da dojde utre (Dokle, 2007);

Boláecci ruka da ti povene (Resteljica), Boláječi da staneme zdravo i živo (Borje).

Expression ludo (young), which appears in Gorani speech, and especially in national poetry of Gora, have the meaning of ,young man, hero, dear", is the calc made of greek word $\mu \omega \rho o s$. Adjective $l u d / a / o$ have the meaning of mlad/a/o in Gorani language and national poetry of Gora. Form for neuter ludo have been formed from noun and it means dijete: Ona ima samo jeno ludo („Ima jedno dijete“); Ga turif so dve lude (,Ostavio je sa dvoje djece.“) „Da som znalo, ore ludo mlado“ (Hasani, 1987, p. 158)

„- Dej đidi, ludo dejče, adžamijiče,

- Dej đidi, ludo dete, bre budalino“ (Hasani, 1987, p. 183)

When performing complex words in Gora speech, we can single out a type which is inappropriate to Slavic languages. These are complex words made of two imperative forms. These expressions can be named same, and they can ever appear with the same meaning of material object (brkajvari - kind of flummery), but can be also used as adverb. Greek language also knows for supstivition of imperatives. 
Brkájvari, idíhodi, idídojdi, perínosi, panístani, stanílegni, períderi, kosínosi, krpítrpi, dojdíprojdi, stájistaj.

Based to Greek verb $\pi \varepsilon \rho v \alpha \omega$ - have good time, live - with the meaning of $i$ live a good life, it have been calced in Gorani language as pominujem, pominu $^{w}$ am with the same meaning:

Ka pominujete? - Hubavo pominuwam so braća. (How do you live? - I live good/I live with my brothers).

Greek verb $\theta \varepsilon \lambda \omega$ have the meaning which would be compatible to- 1. want, 2. love, in Bosnian language. In Gorani language, sakam have the both meanings - want, love:

Sakam malo ljep. (I want bread); On mlogu nja ga saka. (He loves her a lot.)

Verb $\kappa \alpha \theta о \mu \alpha$ in Greek language, beside the meaning of seating, also have the meaning of living. The last meaning is calced in Gorani language as well:

Sedi ke amidža. (Lives with his uncle.); Ke kogo sedi sega? (Where he lives now?)

Greek ó $\delta \varepsilon 10$ - bleak, blasted, is calced in Gorani language with pust, da zapusteš, pusto da ti bide (damned):

„Toku puste pare nemaš“ (Hasani, 1987, 2); „za devet puste godine“ (Hasani, 1987, p. 13); ,dalek na daleko na pusti gurbet“" (Hasani, 1987, p. 28); „Puste ostanale, Imere be brate, edrenske pampuri““ (Hasani, 1987, p. 29); ,pusto bilo, pusto ostanalo“ (Hasani, 1987, p. 82).

In one of the wedding songs, written down in Borje in Albania, the girls are singing: „Fere, fere, tenke kore“ (Dokle, 2000, p. 379). Word fere is of Greek origin (< grč. $\varphi \varepsilon \rho \varepsilon-$ bring) and is not being used in daily speech of Gora.

\section{CONCLUSION}

Multiplicity of words and calcs of Greek origin that appear in the speech and national poetry of Gora, testify the intensive relation between them and affirms the probity of the inhabitants which, when explaining the phonological and grammatical appearances, gives important place to the interlinguistic contact within Balkan environment.

It is doubtless that the Greek language, and later Turkish language too, have left most traces in modelling the Balkan lexicon. Concerning the Gora speech and national poetry of Gora, it is important to underline the influence of Greek language which was used mostly. Many words, and especially calcs taken from this language, sometimes represents the literal translation.

\section{REFERENCES}

- $\quad$ Dokle, N. (2000). Goranski narodni pesni. Skopje. Macedonia: Patria.

- Dokle, N. (2007). Rečnik goranski (našinski) - albanski. Sofija. Bulgaria: Štamparija akademije nauka „Prof. Marin Drinov“.

- Hasani, H. (1987). Goranske narodne pesme. Priština, Kosovo: Jedinstvo.

- Chomsky, N. (1972). Gramatika i um. Beograd. Serbia: Nolit.

- Koneski, B. (1966). Istorija makedonskog jezika. Beograd. Serbia: Prosveta.

- Ivić, P. (1991). Izabrani ogledi I- III. Niš. Serbia.

- Mladenović, R. (2001). Govor šarplaninske župe Gora. Beograd. Serbia: SANU. 